\section{ANNUAL REPORT OF THE INDIAN HEAD BLUEBIRD TRAIL}

by Lorne Scott, Indian Head

April 5, 1970 marked the completion of the longest bluebird trail in the world. On that day, the Saskatoon Junior Natural History Society extended their trail to Raymore, Saskatchewan to meet mine, which in turn links up at Broadview with the trail established by John Lane and the Brandon Junior Bird Club. Thus was completed a continuous line of bird houses from Beaver Creek, south of Saskatoon, to MacGregor, Manitoba.
After working on the bluebird project for the past eight years, I now have over 1000 nest boxes. Despite the late spring, Mountain Bluebirds again showed an increase in numbers. In 1969 they occupied 104 houses, and this year 156 houses were used by Mountain Bluebirds. I banded 600 Mountain Bluebirds this past season; of these 63 were adult females and one was an adult male (the first I have banded). Eight bluebirds banded as adult females last year were caught again this year while sitting on nests. Two of these were re-caught in the same house where they were banded

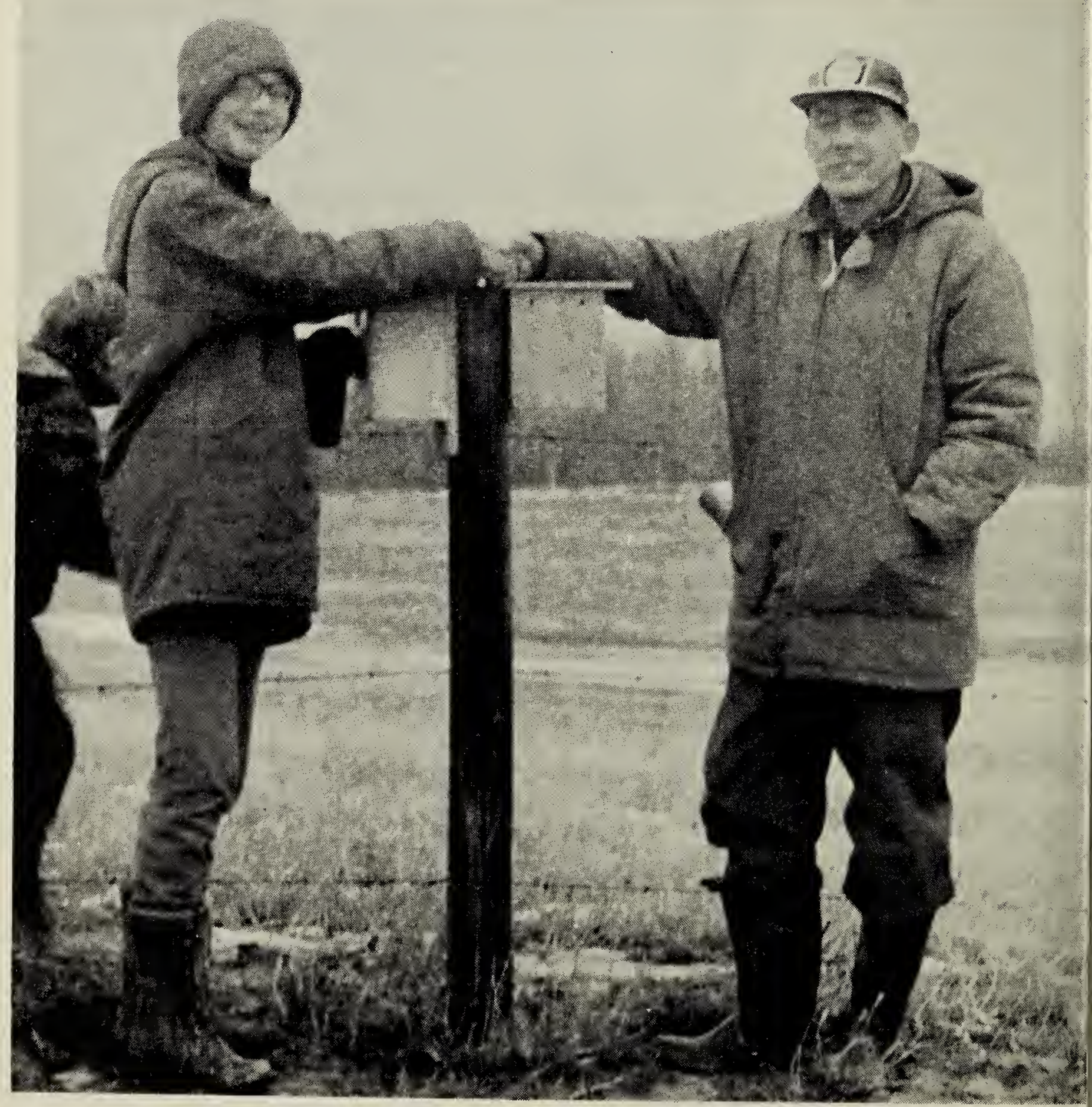

Last link in the Saskatoon - Indian Head Bluebird Trail.

Photo by Gary Seib 
last year. Five were caught within one mile of where they were banded last year, and one was four miles away. It is interesting to note that none of the 357 young bluebirds banded last year were found nesting in any of the houses this year. During the past two years I have banded 1000 bluebirds.

The Tree Swallows also had a successful year despite the fact that House Sparrows occupied many of the older houses. This year there were at least 325 houses occupied by Tree Swallows, compared to 275 in 1969. A total of 850 Tree Swallows was banded this past season, bringing the two-year total to 1450 . There were 123 adult female Tree Swallows banded this year, and 19 of the 125 banded last year were re-caught on nests. Most of them were re-caught within a mile of where they were banded or at the same nest, but one was nesting 75 miles away. Again it was interesting to note that none of the young Tree Swallows banded last year were found nesting in any of the houses.

\section{SASKATOON JUNIORS' BLUEBIRD REPORT, 1970}

by Michael Bantjes and David V. Houston, Saskatoon

The Saskatoon Junior Natural History Society was formed in November 1968 , with seven members between the ages of 10 and 14. It was formed to enable the younger members of the Natural History Society to have active participation in various phases of natural history. We now have over 20 members.

Our main project over the last two years has been the construction and maintenance of a bluebird box trail. It extends from Saskatoon to Raymore with a total of 368 houses, spaced about one-third of a mile apart. The boxes were placed four feet above the ground and at least 100 yards from trees, and 200 yards from farmyards when possible.

During the breeding season we were able to check all the 182 houses within the Saskatoon area (which extends 20 miles east of Hanley) and 55 houses west of Raymore, leaving 131 intervening houses unchecked. Occupancy was as follows:

\begin{tabular}{lrr} 
& \multicolumn{3}{c}{ Saskatoon } & Raymore \\
Tree Swallow ........... & 130 & 38 \\
Mountain Bluebird .... & 8 & 0 \\
House Sparrow ......... & 11 & 6 \\
Empty all year ......... & 15 & 2 \\
Damaged or destroyed & 22 & 9 \\
Used by two species ... & -4 & $\ldots$ \\
\cline { 2 - 2 } & -.4 \\
Total ...................... & 182 & 55
\end{tabular}

We were encouraged by the Mountain Bluebird's increase from three to eight pairs, compared with 1969.

\section{A REPORT FROM ST. CHAD'S GIRLS' SCHOOL OUTINGS CLUB}

\author{
by Jane Richardson, Semans
}

The school year of 1969-70 was the second and final year of the St. Chad's Outings Club. Its life was only brought to an end because the school was forced to close. All members of the club woulu' like to thank Lorne Scott of the Museum of Natural History in Regina for his leadership and interest in the club. Thanks also goes to the Sisters for their assistance and guidance within the Outings Club.

Our activities were varied and took place at all hours. For example, last October at 5:30 in the morning, eleven of our members visited the Fred Bard Nature Refuge near Regina. Here Whistling Swans were observed resting during their long migration south. Prairie Dogs, which many of the girls had never seen before, were active in the early morning. We also visited the Interpretive Centre before returning to the city and a day of classes.

November started out with the club attending an Audubon Screen Tour film sponsored by the Regina Natural History Society and the Museum. Later in the month a field trip was taken to Lake Marguerite which is located south of Indian Head. The highlight of the trip was discovering several bison skulls and bones along the lake shore. Beaver work was also discovered in cut 